\title{
The impact of geographical indications on farm incomes in the EU olives and wine sector
}

\author{
Kathrin Poetschki \\ Agricultural Economics and Rural Policy, Wageningen University and Research, \\ Wageningen, The Netherlands and \\ Agrobusiness Niederrhein e.V., Straelen, Germany, and \\ Jack Peerlings and Liesbeth Dries \\ Agricultural Economics and Rural Policy, Wageningen University and Research, \\ Wageningen, The Netherlands
}

The impact of geographical indications

Received 12 December 2020 Revised 24 May 2021 26 August 2021

Accepted 23 October 2021

\begin{abstract}
Purpose - Geographical indications (GIs) are expected to stimulate rural development by increasing the viability and resilience of farms in disadvantaged and remote areas. However, little quantitative evidence exists to support this expectation. This study fills this knowledge gap by quantitatively analyzing the effect of GI adoption on farm incomes in the EU olives and wine sectors.

Design/methodology/approach - The analysis uses data from the Farm Accountancy Data Network and EUROSTAT and an endogenous switching regression model to analyze the impact of GI adoption on farm incomes for specialized quality wine and olives producers in the year 2014.

Findings - The results show that GI adoption significantly improves farm incomes in both the olives and the wine sector.

Research limitations/implications - The research uses data from the farm accountancy data network $(\mathrm{FADN})$. This is seen as a limitation of the analysis. The research raises some concerns about the appropriateness of FADN for the assessment of farmers' involvement in food quality schemes and a reconsideration of FADN as a tool for farm performance analysis is advised.

Originality/value - This is one of few quantitative studies of the impact of geographical indications on farm performance. Furthermore, it gives insights into the mechanisms by which GI can affect farm incomes.

Keywords Geographical indication, PDO, PGI, EU, Farm income, Impact assessment, Adoption, Food quality scheme

Paper type Research paper
\end{abstract}

\section{Introduction}

There is increasing concern in the EU about the sustainability challenges faced by rural areas. Apart from environmental aspects, these concerns relate to issues such as the viability of rural livelihoods; land abandonment; deteriorating service provision; ageing farm populations (see e.g. Hazell, 2005; Recanati et al., 2019; Weissteiner, 2011). Moreover, farm incomes are significantly lower than incomes in other sectors and public support provides on

(C) Kathrin Poetschki, Jack Peerlings and Liesbeth Dries. Published by Emerald Publishing Limited. This article is published under the Creative Commons Attribution (CC BY 4.0) licence. Anyone may reproduce, distribute, translate and create derivative works of this article (for both commercial and noncommercial purposes), subject to full attribution to the original publication and authors. The full terms of this licence may be seen at http://creativecommons.org/licences/by/4.0/legalcode

The authors are grateful for financial support received from the European Horizon 2020 project Strength2Food, grant agreement No 678024. We furthermore acknowledge the valuable comments of four anonymous reviewers and comments received at the 170th seminar of the European Association of Agricultural Economics in Montpellier.

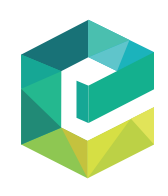

British Food Journal Vol. 123 No. 13, 2021 pp. 579-598
Emerald Publishing Limited DOI 10.1108/BFJ-12-2020-1119 
$\mathrm{BFJ}$

123,13 average $32 \%$ of EU farm incomes (European Commission, 2009, 2017). This share is larger for small farms and in less favored areas (LFAs) (Hill and Brandley, 2015).

In 1992, the EU introduced food quality regulation in support of Geographical Indications (GI) - Protected Designation of Origin (PDO) and Protected Geographical Indication (PGI) (Council of the European Communities, 1992). The goal of these food quality schemes is to create added value by linking food products to unique physical characteristics, the environment, social ties and/or traditions of their origin (Giovannucci et al., 2009). They are an alternative to cost-minimizing strategies and are expected to especially benefit small farms and farms in disadvantaged areas that have difficulties to compete with larger and more efficient producers (Hajdukiewicz, 2014). Moreover, GI offer opportunities for endogenous development in rural areas if more value added remains at the farm level and, consequently, in rural areas (Gangjee, 2017).

GI correspond to consumers' increasing demand for local, traditional and more extensively produced food (Verbeke et al., 2012). Food is increasingly regarded by consumers as much more than physical sustenance, representing a major construct of global intangible cultural heritage (Dixit, 2020). Hence, GI are linked to product differentiation strategies, which allow to obtain price premiums (Giovannucci et al., 2009; Van Haeck et al., 2019; Van Ittersum, 2002). However, GI may also lead to higher production costs, e.g. for registration, application of specifications, marketing and control, which might exceed extra revenues (Hajdukiewicz, 2014). Another potential threat to income gains is that there is too little market power of farmers vis-à-vis downstream stakeholders in the supply chain (traders, processors, retailers), who do not pass on the higher profits that are earned from product differentiation (Agricultural Markets Task Force, 2016).

Recent studies have investigated the contribution of GIs to environmental sustainability (Arfini and Bellassen, 2019; Belletti et al., 2015, 2017). Fewer research studies focus on the implications of GI on the economic dimension of sustainability. Cei et al. (2018a) provide an overview of the existing research on the impact of GI adoption on farmers' economic sustainability. They conclude that the literature on GI effects on farmers mainly focuses on a specific territory or product and is based on case-study analysis. Comprehensive analyses are therefore lacking. Moreover, the economic indicators that are used are often limited to observed prices, costs and price-cost differences. Hence, there is a need for assessments based on broader indicators such as value added and profitability (Cei et al., 2018a). The current study will, therefore, focus on the direct effect of the added value of GI submitted through the supply chain and the costs of GI adoption as translated in farm incomes.

Moreover, the likelihood of adoption and the resulting effects of GIs are contextspecific and may differ across spatial and sectoral scales (see e.g. Deselnicu et al., 2013). In the EU, GIs are most prevalent in the Mediterranean countries (Cei et al., 2018a; Jantyik and Torok, 2020). Traditional Mediterranean agri-food sectors, such as wine and olive oil, provide an interesting case of comparison with respect to the implications of GI adoption on economic sustainability. While some similarities between the two sectors can be observed (e.g. climate conditions for growing and the need for processing of raw materials), there are also clear distinctions with relevance to GIs. For instance, the degree of market differentiation is higher and certifications of origin have been used for a longer time and are more widespread in the wine sector than in the olive oil sector (Cacchiarelli et al., 2016). Extensive research has been done on the environmental sustainability performance of the wine industry (Merli et al., 2018; Rugani et al., 2013; Szolnoki, 2013). Some studies have also attempted to link environmental sustainability performance in wine production to participation in food quality schemes (see e.g. Vázquez-Rowe et al., 2013). However, little attention has been paid to the economic sustainability of GI wine production, Bresciani et al. (2016a, b) being notable exceptions. 
The objective of this paper is, therefore, to evaluate the impact of EU GI in the wine and olives sector on farm incomes using an extensive sample of farms across different EU member states. The quantitative analysis is based on data taken from an unbalanced panel from the Farm Accountancy Data Network (FADN) for the year 2014, complemented with information from EUROSTAT. FADN presents the only comprehensive source of farm-level data that allows for an EU-wide, quantitative analysis of farm performance. For the assessment of the impact of GI adoption on farm incomes, an endogenous switching regression model was estimated to control for farmers' self-selection into GI adoption.

\section{Literature review and theoretical considerations on GI impact}

GI certify a unique product quality that is linked to the product's origin. This leads to product differentiation and potentially to price premiums paid by consumers (see e.g. Lopez-Bayon et al. (2020) for studies on consumer willingness-to-pay for geographical indications). MonierDilhan et al. (2020) find positive price premiums in 27 case studies of GI in the EU. Török et al. (2020), on the other hand, find mixed results in their review of GI effects on price premiums. Several factors may influence whether price premiums are achieved through GIs and whether this results in positive income effects for producers. The sector in which the GI is produced may be an important determinant. Deselnicu et al. (2013) find that price premiums for GI in the wine and olive oil sectors are generally lower, because there are alternative means of differentiation in these sectors through brands. Carbone et al. (2018) conclude that food quality schemes, such as PDO, PGI and organic, do not bring additional value to consumers of olive oil. Cacchiarelli et al. (2016) find that prices for wine are more sensitive to GI certification than for olive oil.

Differences across sectors may also be related to the prevailing market type under which GI are produced. In concentrated markets with few large producers, a higher price and markup (i.e. price minus marginal cost) can be achieved. On the other hand, if a differentiated GI product is produced by several firms, then competition increases and the mark-up will go down. While a GI certification can be shared by several producers and hence can function as a collective brand strategy (Borg and Gratzer, 2013), its effectiveness in improving producer incomes is likely to decrease with the number of producers joining.

Farmers may also not market GI products directly but produce ingredients for a GI that is produced by a processing company. PDO products usually have strict specifications with respect to their ingredients' origin, while ingredients for PGI products can theoretically be sourced from all over the world. Consequently, price and income effects might differ depending on which GI scheme is applied. If the production of the GI product does not require ingredients from a specific origin (which is the case, for example, for PGI products) then the output of farmers in the GI value chain can be easily substituted and farmers do not have market or pricing power, even if they produce ingredients for a GI product. In line with this expectation, Deselnicu et al. (2013) find that price premiums are higher on average for PDO products than for PGI.

Moreover, there may be a distinction between supply chains led by investor-owned firms or by cooperatives. As mentioned earlier, cooperative ownership structures are predominant in the wine industry, and in some of the main olive oil producing countries in the EU (Langreo, 2010; Lopez-Bayon et al., 2018). Investor-owned processors might not forward the price premium paid by consumers to farmers. In the case of a GI chain with a cooperative processor, on the other hand, farmer members can either benefit from higher prices paid for their GI ingredients or via the increase in value of their member bonds if the GI adds value on the market.
The impact of geographical indications 
BFJ

123,13

582

Finally, we discuss the existing knowledge on the impact of GIs on rural economies. The EU GI policy explicitly targets regional prosperity by attempting to improve farmers' incomes and retaining rural population in less-favored or more remote areas (Council of the European Communities, 1992). A comprehensive, EU-wide evaluation of GI measures identified several positive effects for rural areas (European Commission, 2020). These include increased employment in GI marketing chains at a faster pace than in the food and drinks sector as a whole, an increase in the number of farms and processors involved in GI chains, and improved opportunities for diversification through strong relationships between GI chains and tourism and/or on-farm processing activities. In their review of the literature on GI impact on rural economies, Török et al. (2020) find mixed evidence and highlight several conditions that need to be fulfilled for GIs to substantially contribute to rural development, such as strong traditions, organizational capacity and institutional support. Donati et al. (2020) find a major positive contribution of PGI production to the local economy, especially in animal production sectors. Mattas et al. (2020) review the literature and find especially strong spillovers from PDO products to rural development, indicating also indirect benefits for other rural sectors and the preservation of cultural heritage. Cei et al. (2018b) provide one of the few econometric studies of GI impact on rural economies and find a significant positive effect based on data for Italy.

\section{Methods and data}

\subsection{Data and farm sample}

Data are extracted from the Farm Accountancy Data Network (FADN) containing information about individual farms across 28 member states of the European Union in the year 2014 (European Commission, 2016). In addition, a dataset that was prepared by Van de Pol (2017) and which is based on EUROSTAT data adds variables at the NUTS2 [1] and national level. FADN uses three criteria for stratification to ensure that specific categories of farms are sufficiently represented in the sample: region, economic size and type of farming (European Commission, 2016). This ensures that the FADN sample covers the heterogeneity of farms in the European Union (EU28). Since the dataset of Van de Pol (2017) does not contain information about Croatia, we excluded Croatia from the sample. The relevant question about GI adoption was not included in the FADN dataset in France, Germany, Ireland, Lithuania, Luxembourg, Latvia and Slovakia. These countries are therefore excluded from the analysis too. There are also some NUTS2 regions within the remaining EU member states where none of the farms has responded to the GI question. Consequently, impact evaluation also excludes these regions (5 regions in Belgium and 3 regions in Austria), and all NUTS2 regions in the UK except for Northern Ireland.

Among the farms in the remaining dataset, $1 \%$ are GI farms, $90 \%$ are non-GI farms and $4 \%$ produce some GI ingredients or products. The remaining $5 \%$ of the farms in the dataset have missing data. Hence, also these farms with missing data were excluded as well as the farms that claimed to have "some" GI production. This leaves 52,133 farms in the 2014 sample, with 1\% GI farms and 99\% non-GI farms respectively. Next, we focus on olives and quality wine specialists. Figure 1 shows that there is a reasonable number of GI farms in the olives and wine sectors, which is necessary for impact evaluation. There are $300 \mathrm{GI}$ and 937 non-GI quality wine specialists. The second largest GI farm group are olives specialists. There are 55 GI and 981 non-GI olives specialists.

\subsection{Endogenous switching regression model}

In the case of GI adoption, which farms adopt GI and which farms do not, is not exogenously determined, in other words, adoption is caused by self-selection. This self-selection is likely to be based on individual expected benefits or the expected utility of GI adoption, which is 

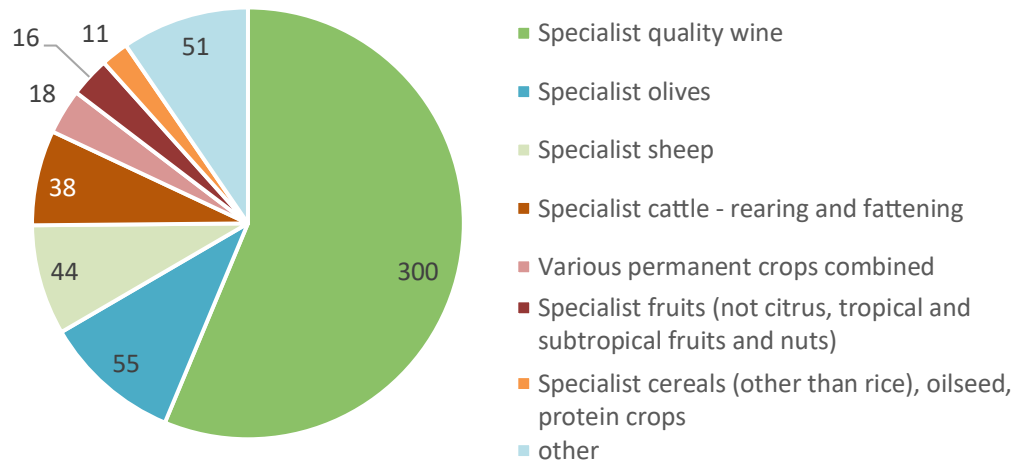

Source(s): Authors' own representation based on FADN sample
The impact of geographical indications

583

Figure 1.

Prominent farm types among GI farms, 2014

positive for adopters and zero or negative for non-adopters. Consequently, an estimation technique is needed that corrects for self-selection. Several approaches exist to address the issue of self-selection, including propensity score matching (PSM), inverse probability weighted regression adjustment (IPWRA), and endogenous switching regression (ESR). Among these, the ESR model has three considerable advantages according to Li et al. (2020): (1) it addresses selection bias caused by observed as well as by unobserved differences between control and treatment groups; (2) it provides more information by estimating both a selection equation and two outcome equations (one for the treatment and one for the control group); (3) it calculates average treatment effects (ATT) of GI adoption on farm performance. The validity of the ESR model has been confirmed in previous studies including Di Falco et al. (2011), Khonje et al. (2015) and Lokshin and Sajaia (2004). We therefore employ the ESR model in our analysis.

ESR applies a two-stage framework. First, a selection equation is estimated by a probit model with a dependent variable that reflects whether the expected benefits of GI adoption for a farmer are positive or not, and with determinants of adoption as explanatory variables:

$$
T_{i}^{*}=Z_{i} \alpha+\varepsilon_{i} \text { with } T_{i}=\left\{\begin{array}{l}
1 \text { if } T_{i}^{*}>0 \\
0 \text { otherwise }
\end{array}\right.
$$

where $T_{i}$ is 1 for all farms who expect that they gain from GI adoption, while it is zero for all other farms. $Z_{i}$ is a vector that includes variables that influence the adoption decision (Di Falco et al., 2011). The selection equation should include a selection instrument that affects the adoption decision but not farm income (Khonje et al., 2015). A falsification test helps to identify valid instruments. They must be jointly statistically significant in the selection equation, but jointly statistically insignificant in the outcome equation.

The second stage of the model consists of two outcome regression equations that are estimated by an OLS regression with selectivity correction (Khonje et al., 2015). Equation (2a) is used for adopters, while equation (2b) represents non-adopters, where $X_{1 i}$ and $X_{0 i}$ are vectors of exogenous covariates, $\beta_{1}$ and $\beta_{0}$ are the respective vectors of parameters, and $w_{1 i}$ and $w_{0 i}$ are random disturbance terms.

$$
\begin{array}{ll}
Y_{i}^{1}=\beta_{1} X_{1 i}+w_{1 i} & \text { if } T_{i}=1 \\
Y_{i}^{0}=\beta_{0} X_{0 i}+w_{0 i} & \text { if } T_{i}=0
\end{array}
$$

In equations (2a) and (2b), $X_{0 i}$ and $X_{1 i}$ capture the selection bias arising from observed factors. However, unobserved factors that can cause selection bias should also be accounted 
BFJ 123,13

\section{4}

for. In the ESR model, the inverse Mill's ratios are calculated after estimating equation (1) and then included in equations (2a) and (2b) to capture the unobserved selection bias (Li et al., 2020). Estimating the ESR model can be done by the Stata command movestay. This estimation technique provides four relevant estimates: the expected outcome of GI farms with GI adoption, the expected outcome of non-GI farms without GI adoption, and the two counterfactuals. These four cases are summarized in Table 1.

Within the ESR framework, the treatment effect of GI adoption on farm performance can be calculated by comparing the expected values of farm performance for GI adopters with the expected values of farm performance for adopters in the case that they had not adopted. The average treatment effect of GI adoption for GI farms is then:

$$
\mathrm{ATT}=E\left(Y_{i}^{1} \mid T_{i}=1\right)-E\left(Y_{i}^{0} \mid T_{i}=1\right)
$$

For non-adopters, the expected average treatment effect is:

$$
\mathrm{ATU}=E\left(Y_{i}^{1} \mid T_{i}=0\right)-E\left(Y_{i}^{0} \mid T_{i}=0\right)
$$

In addition, effects of base heterogeneity $(\mathrm{BH})$ can be calculated. Base heterogeneity may occur because, for example, the GI policy is intended to help farms with difficulties to compete on the global market, so it is assumed that GI farms had a lower farm income than nonadopters before they started using $\mathrm{GI}(\mathrm{BH}<0)$. For adoption, $\mathrm{BH}$ is:

$$
\mathrm{BH}_{1}=E\left(Y_{i}^{1} \mid T_{i}=1\right)-E\left(Y_{i}^{1} \mid T_{i}=0\right)
$$

For non-adoption, $\mathrm{BH}$ is equal to:

$$
\mathrm{BH}_{0}=E\left(Y_{i}^{0} \mid T_{i}=1\right)-E\left(Y_{i}^{0} \mid T_{i}=0\right)
$$

Finally, transitional heterogeneity $(\mathrm{TH})$ indicates whether the effect of GI adoption is the same for adopters and non-adopters (if they would adopt GIs). If TH is positive, non-adopters would not gain as much from adoption as the adopters do.

$$
\mathrm{TH}=\mathrm{ATT}-\mathrm{ATU}
$$

\subsection{Model variables}

For the specification of the ESR model there are four categories of variables needed: the outcome variable; a treatment variable that indicates whether a farm is producing

\begin{tabular}{llll}
\hline & $\begin{array}{l}\text { Decision stage } \\
\text { Adoption }\end{array}$ & No adoption & Treatment effects \\
\hline GI farms & $(a) E\left(Y_{i}^{1} \mid T_{i}=1\right)$ & $(c) E\left(Y_{i}^{0} \mid T_{i}=1\right)$ & ATT \\
Non-GI farms & $(d) E\left(Y_{i}^{1} \mid T_{i}=0\right)$ & $(b) E\left(Y_{i}^{0} \mid T_{i}=0\right)$ & ATU \\
Heterogeneity effects & $\mathrm{BH}_{1}$ & $\mathrm{BH}_{0}$ & TH
\end{tabular}

Note(s): (a) and (b) are observed, while (c) and (d) are counterfactuals

$T_{i}=1$ if the farm produces (ingredients for) GI products and zero otherwise

$Y_{i}^{1}$ : farm income if farm adopted GI

$Y_{i}^{0}$ : farm income if farm did not adopt GI

Table 1. Conditional expectations and treatment effects ESR model
ATT: treatment effect on the treated (GI farms)

ATU: treatment effect on the untreated (non-GI farms)

$\mathrm{BH}_{t}$ : effect of base heterogeneity for GI farms $(T=1)$, and non-GI farms $(T=0)$

$\mathrm{TH}=$ (ATT-ATU), i.e. transitional heterogeneity

Source(s): Di Falco et al. (2011, p. 837) 
(ingredients for) GI products; exogenous control variables that affect the outcome variable and the adoption decision; instrumental variables that affect the decision to adopt GI, but not the outcome variable. Appendix A1 provides details on the variable definitions and their sources.

3.3.1 Outcome variable. Farm net income (FNI) will be used as the outcome variable and indicator of farm performance. It reflects the remuneration to fixed factors of production and the farmer's risks in the accounting year (loss/profit) in Euro. In the FADN dataset, FNI is calculated as indicated by equation (8), where total output is equal to the production volume times farm gate prices, which is the same as revenues. Total intermediate consumption equals the sum of specific costs and farming overheads. External factors cover wages, rent and interests paid.

$$
\begin{aligned}
\text { Farm net income }(\mathrm{FNI})= & \text { Total output }- \text { Total intermediate consumption } \\
& + \text { Balance current subsidies and taxes }- \text { Depreciation } \\
& + \text { Balance subsidies and taxes on investments } \\
& - \text { Total external factors }
\end{aligned}
$$

3.3.2 Treatment variable. The FADN dataset includes a variable of GI uptake, namely whether farmers are involved in the production of (ingredients for) PDO and/or PGI products. This question was answered by "no PDO/PGI production" (code 1), "only PDI/PGI production" (code 2) or "some PDO/PGI production" (code 3). A treatment variable T was generated with $T=1$ for GI adopters (code 2) and $T=0$ for the remaining farms. Only farms that only produce GI (code 2) are used to compare with farms that do not use any GI at all (code 1). The category "some PDO/PGI products" is too imprecise to guarantee that the impact estimates are unbiased. The given dataset only allowed estimating joint PDO/PGI effects. It was not possible to estimate treatment effects for each GI scheme separately as the GI variable encompasses different GI schemes. This poses a possible risk of downward biased estimates in case that positive income effects for one GI label are cancelled out by negative (or less positive) impacts of other GI labels.

3.3.3 Control variables. To estimate the effect of GI on farm income, all other factors that can explain variations in farm income should be taken into account. Farm income relies on profits, i.e. the difference between total revenue and total cost of agricultural production, where total costs include variable and fixed costs. Several factors can affect the determinants of farm income. First, natural or geographical constraints such as climate, soil fertility or slope can influence the efficiency with which inputs are transformed into outputs (Van de Pol, 2017). Second, farm size may affect input prices as large farms can benefit from economies of scale and potential volume discounts when buying inputs or paying for services. Third, opportunity costs of farm labor depend on the employment opportunities outside of the farm business, and these will be higher the closer the farm is to urban areas (Meraner et al., 2015). Fourth, the farm system and its location can influence the exposure of the farm to risks and price volatility and this in turn can influence the cost and access to capital (Beckmann and Schimmelpfennig, 2015; Prakash, 2011). Next, land prices influence the access to land, which in some cases becomes a limiting factor of production (Beckmann and Schimmelpfennig, 2015). In addition, institutional and legal constraints might pose limitations to profit maximization. Furthermore, the quantity of products sold on the market is directly affected by farm household consumption of own products (European Commission, 2011). Infrastructure such as roads, railways, harbors, Internet and institutions such as cooperatives also affect the possible marketing channels and the cost of trading, both for inputs and outputs. Finally, farm income is affected by the farm gate price, which in turn 
$\mathrm{BFJ}$

123,13

586

depends on farm size, degree of product differentiation, competition from close substitutes and market concentration through their influence on bargaining power.

Based on this discussion and the available data, the following variables were selected as covariates: total output (OUT), specific costs (SPC), overheads (OVER), total utilized agricultural area (UAA), paid labor in annual working units (PL), unpaid labor in annual working units (UL), liabilities (LIA), external factors (EXT), machinery (MACH), gross domestic product per capita in the NUTS2 region (GDPC), farm household consumption (FHC), as well as dummies for organic production $(\mathrm{ORG}=1$ if the holding applies only organic farming), less favored area (LFA $=1$ if the majority of the holding is situated in LFA) and mountain area (MA $=1$ if the majority of the holding is situated in MA). Appendix A2 presents the correlation matrix for the whole set of explanatory variables. Because of high and significant correlation coefficients, we have decided to remove the variables OUT (total output) and OVER (overheads) from the analyses that follow.

3.3.4 Selection instruments. Several combinations of potential instruments have been tested to find variables that are not jointly significant in the outcome equation of nonadopters but jointly significant in the selection equation. Transportation costs are often neglected in economic theories, so differences in the number of kilometers of motorway per $1,000 \mathrm{~km}^{2}(\mathrm{MKM})$ and its square (MKM2) are expected to have no or a minor effect on FNI. However, according to Van de $\mathrm{Pol}$ (2017), a certain minimum of MKM is required for farms to be interested in adopting GI, whereas too much MKM (high MKM2) reduces the probability of uptake. The reason for this is that farms with excellent access to markets and relatively low transport costs have a competitive advantage and can better compete on the bulk market (without product differentiation via GI or other means). Indeed, MKM and MKM2 fulfil the requirements for valid instruments for the sub-samples of quality wine specialists and olives specialists. Equations (9)-(11) represent the models for the impact assessment. Equations (9) and (10) are the models for the outcome equations for GI adopters and non-adopters, respectively. Equation (11) represents the selection model.

Outcome equation for GI farms:

$$
\begin{aligned}
\mathrm{FNI}^{1}= & \beta_{0}^{T}+\beta_{1}^{T} \mathrm{SPC}+\beta_{2}^{T} \mathrm{UL}+\beta_{3}^{T} \mathrm{PL}+\beta_{4}^{T} \mathrm{UAA}+\beta_{5}^{T} \mathrm{LIA}+\beta_{6}^{T} \mathrm{EXT}+\beta_{7}^{T} \mathrm{LFA}+\beta_{8}^{T} \mathrm{MA} \\
& +\beta_{9}^{T} \mathrm{ORG}+\beta_{10}^{T} \mathrm{MACH}+\beta_{11}^{T} \mathrm{GDPC}+\beta_{12}^{T} \mathrm{FHC}+w_{1 i}
\end{aligned}
$$

Outcome equation for non-GI farms:

$$
\begin{aligned}
\mathrm{FNI}^{0}= & \beta_{0}^{T}+\beta_{1}^{T} \mathrm{SPC}+\beta_{2}^{T} \mathrm{UL}+\beta_{3}^{T} \mathrm{PL}+\beta_{4}^{T} \mathrm{UAA}+\beta_{5}^{T} \mathrm{LIA}+\beta_{6}^{T} \mathrm{EXT}+\beta_{7}^{T} \mathrm{LFA}+\beta_{8}^{T} \mathrm{MA} \\
& +\beta_{9}^{T} \mathrm{ORG}+\beta_{10}^{T} \mathrm{MACH}+\beta_{11}^{T} \mathrm{GDPC}+\beta_{12}^{T} \mathrm{FHC}+w_{0 i}
\end{aligned}
$$

Selection equation:

$$
\begin{aligned}
T= & \alpha_{0}+\alpha_{1} \mathrm{SPC}+\alpha_{2} \mathrm{UL}+\alpha_{3} \mathrm{PL}+\alpha_{4} \mathrm{UAA}+\alpha_{5} \mathrm{LIA}+\alpha_{6} \mathrm{EXT}+\alpha_{7} \mathrm{LFA}+\alpha_{8} \mathrm{MA} \\
& +\alpha_{9} \mathrm{ORG}+\alpha_{10} \mathrm{MACH}+\alpha_{11} \mathrm{GDPC}+\alpha_{12}^{T} \mathrm{FHC}+\alpha_{13} \mathrm{MKM}+\alpha_{14} \mathrm{MKM} 2+\varepsilon_{i}
\end{aligned}
$$

Table 2 summarizes the differences in the model variables between adopters and nonadopters, which are calculated by taking the mean of non-adopters minus the mean of adopters. Among olives specialists, adopters have a higher average FNI than non-adopters. If adoption would be purely random, the difference of 4,187 EUR could be interpreted as the effect of GI adoption. However, as mentioned before, farmers select themselves into the 


\begin{tabular}{|c|c|c|c|c|}
\hline & & Quality wine specialists 2014 & Olives specialists 2014 & The impact \\
\hline FNI & Farm net income & $28314.93^{* * *}$ & -4186.59 & indication \\
\hline SPC & Specific costs & 11247.83 & 1755.08 & \\
\hline UAA & Total utilized agricultural area & $4.84^{* *}$ & 1.31 & \\
\hline UL & Unpaid labor & $0.06^{*}$ & $-0.09 *$ & \\
\hline PL & Paid labor & $-0.85 * * *$ & 0.09 & \\
\hline LIA & Liabilities & $-25111.22^{* * *}$ & 3279.99 & 587 \\
\hline EXT & External costs & -1948.93 & 2845.52 & \\
\hline ORG & Organic farming & $-0.02 * *$ & 0.02 & \\
\hline LFA & Less favored area & -0.003 & $-0.17 * * *$ & \\
\hline MA & Mountain area & -0.01 & $0.10^{*}$ & \\
\hline GDPC & GDP per capita (NUTS2) & $3.14^{* * * *}$ & 0.55 & \\
\hline $\mathrm{MACH}$ & Machines & $-17683.87 * * *$ & $7109.89 * *$ & \\
\hline FHC & Farm household consumption & 32.21 & $262.61^{* *}$ & \\
\hline MKM & km motorway & $-4.79 * * *$ & $3.16^{* * *}$ & \\
\hline MKM2 & $\left(\mathrm{km}\right.$ motorway) ${ }^{2}$ & $-444.87 * * *$ & 87.01 & $\begin{array}{l}1 \text { ifferences between } \\
\text { if }\end{array}$ \\
\hline $\begin{array}{l}\text { Note(s) } \\
\text { level; ** }\end{array}$ & $\begin{array}{l}\text { ference }=\text { mean (non-adopters) } \\
\text { hificant at } 1 \% \text { level }\end{array}$ & In (adopters); *Significant at 1 & evel; **Significant at $5 \%$ & $\begin{array}{r}\text { non-adopters and } \\
\text { adopters }\end{array}$ \\
\hline
\end{tabular}

schemes. In addition, the differences are not significant. For quality wine specialists, the differences are positive and significant, which would mean that non-adopters earn higher FNI than GI adopters.

\section{Results}

Results of the endogenous switching regression estimated by full information maximum likelihood are summarized in Table 3. The first column presents the estimates of the selection equation. The second and third columns report the estimates of the outcome equations for adopters and non-adopters, respectively.

First, we discuss the results of the estimated selection equation. The results for wine specialists show that farms are more likely to use GI the more liabilities (LIA) and machines $(\mathrm{MACH})$ and the less land (UAA) and farm household consumption (FHC) they have. Organic production (ORG) and location in a mountainous area (MA) seem to positively affect GI adoption, while welfare in the NUTS2 region (GDPC) decreases the probability of GI uptake. Olives specialists are more likely to use GI if they are located in a less favored area (LFA), and if they have lower farm household consumption.

Columns (2) and (3) report the estimates of the outcome equations. Given the result of the likelihood-ratio test for joint independence of the three equations, the outcome equations of adopters and non-adopters are significantly different. Heterogeneous effects occur when treated and control groups are differently affected by control variables. For example, for wine specialists, total land (UAA) has a significantly positive effect on FNI for adopters and a significantly negative effect on FNI for non-adopters. Consequently, any model that would assume common impacts is likely to give biased estimates because of sample heterogeneity.

For wine specialists, FNI tends to be higher the more unpaid labor (UL) and the less paid labor (PL) the farm has. Land area (UAA) and liabilities (LIA) increase FNI for adopters, while they decrease FNI for non-adopters. The opposite is occurs for the coefficient of external costs (EXT) which is significantly positive for non-adopters and negative for adopters. GI farms located in less favored areas (LFA) or mountain areas (MA) achieve a significantly lower FNI, while non-GI farms in these areas achieve a higher FNI. 
BFJ
123,13

\begin{tabular}{|c|c|c|c|c|c|c|}
\hline Dep. variable & \multicolumn{2}{|l|}{ (1) } & \multicolumn{2}{|c|}{$\begin{array}{c}(2) \\
T=1\end{array}$} & \multicolumn{2}{|c|}{$\begin{array}{c}(3) \\
T=0\end{array}$} \\
\hline \multicolumn{7}{|c|}{ Quality wine specialists } \\
\hline SPC & $-3.7 \mathrm{e}-06$ & $(2.3 \mathrm{e}-06)$ & $1.097 * * *$ & $(0.297)$ & $0.095^{* * *}$ & $(0.024)$ \\
\hline $\mathrm{UL}$ & -0.020 & $(0.076)$ & $25405.090 * *$ & (10125.900) & $33706.680 * * *$ & (5117.440) \\
\hline PL & 0.013 & $(0.020)$ & $-9649.101 * * *$ & (1950.102) & -1133.850 & (1185.800) \\
\hline UAA & $-0.008^{* * *}$ & $(0.002)$ & $507.328 * *$ & $(230.188)$ & $-433.631 * * *$ & (134.755) \\
\hline LIA & $1.1 \mathrm{e}-06^{* *}$ & $(5.6 \mathrm{e}-07)$ & $0.159 * * *$ & $(0.052)$ & $-0.112 * *$ & $(0.567)$ \\
\hline EXT & $2.6 \mathrm{e}-06$ & $(1.8 \mathrm{e}-06)$ & $-0.668^{* * * *}$ & $(0.244)$ & $1.473^{* * *}$ & $(0.131)$ \\
\hline LFA & -0.065 & $(0.106)$ & $-32585.380^{* *}$ & (13724.350) & 8376.857 & (9051.003) \\
\hline MA & $0.272^{* *}$ & $(0.109)$ & $-34208.370 * *$ & (15050.810) & 409.979 & $(8376.500)$ \\
\hline ORG & $0.584^{* *}$ & $(0.249)$ & 5354.665 & (27870.950) & -41232.140 & $(26058.100)$ \\
\hline MACH & $3.0 \mathrm{e}-06^{* * *}$ & $(1.0 \mathrm{e}-06)$ & $-0.168^{* *}$ & $(0.078)$ & -0.088 & $(0.081)$ \\
\hline GDPC & $-0.086^{* * *}$ & $(0.009)$ & -1671.658 & (1146.161) & -34.341 & (673.914) \\
\hline $\mathrm{FHC}$ & $-0.000^{*}$ & $(0.000)$ & 8.036 & $(9.658)$ & 3.742 & $(6.376)$ \\
\hline MKM & 0.004 & $(0.008)$ & & & & \\
\hline MKM2 & $0.000^{* * * *}$ & $(0.000)$ & & & & \\
\hline Const & $0.781^{* * * *}$ & $(0.222)$ & 56685.900 & (40805.310) & $-45774.610 * *$ & (18169.870) \\
\hline$\sigma_{i}$ & & & $92829.740 * * *$ & (1092.753) & $136842.10 * * *$ & $(2329.124)$ \\
\hline$\rho_{i}$ & & & -0.029 & $(0.229)$ & $-0.929 * * *$ & $(0.011)$ \\
\hline$N$ & 1237 & & 300 & & 937 & \\
\hline \multicolumn{7}{|c|}{ Olives specialists } \\
\hline SPC & $-1.4 \mathrm{e}-05$ & $(0.000)$ & 0.039 & (1.568) & $1.241 * * *$ & $(0.171)$ \\
\hline UL & 0.195 & $(0.148)$ & -9522.155 & (11318.650) & $7493.291^{* *}$ & (2963.504) \\
\hline PL & 0.225 & $(0.237)$ & $83091.230 * * *$ & (23628.910) & 15106.110 *** & (2864.310) \\
\hline UAA & 0.002 & $(0.004)$ & -97.916 & $(237.781)$ & $314.387 * * *$ & $(67.364)$ \\
\hline LIA & $7.1 \mathrm{e}-06$ & $(1.6 \mathrm{e}-06)$ & -0.090 & $(0.562)$ & 0.008 & $(0.216)$ \\
\hline EXT & -0.000 & $(0.000)$ & -1.608 & (1.610) & $-0.658 * * *$ & (0.131) \\
\hline LFA & $0.351^{*}$ & $(0.179)$ & -13425.090 & (12387.970) & -1573.758 & (3697.011) \\
\hline MA & -0.088 & (0.194) & 20041.430 & (13740.430) & $8662.914^{* *}$ & (3363.459) \\
\hline ORG & -0.046 & $(0.200)$ & $-23689.720^{*}$ & (13994.260) & -233.386 & (4025.650) \\
\hline MACH & $-3.9 \mathrm{e}-06$ & $(3.3 e-06)$ & $0.571 * *$ & $(0.281)$ & 0.000 & $(0.048)$ \\
\hline GDPC & -0.008 & $(0.026)$ & 2998.950 & (1993.807) & $-728.479 * *$ & (353.350) \\
\hline FHC & $-0.000^{* * * *}$ & $(0.000)$ & $-22.406 * *$ & (10.554) & $4.148 * * *$ & (1.524) \\
\hline MKM & $-0.038^{* * * *}$ & $(0.012)$ & & & & \\
\hline MKM2 & $0.000 *$ & $(0.000)$ & & & & \\
\hline Const & $-0.905^{*}$ & $(0.503)$ & -5035.802 & (40122.390) & 4039.906 & (7677.868) \\
\hline$\sigma_{i}$ & & & $34511.710 * * *$ & (334.185) & 43097.820 **** & (951.117) \\
\hline$\rho_{i}$ & & & $-0.500 * * *$ & $(0.162)$ & $-0.632 * * *$ & $(0.071)$ \\
\hline$N$ & 1,036 & & 55 & & 981 & \\
\hline
\end{tabular}

Note(s): Stata command movestay FNI OUT SPC OVER UL PL UAA LIA EXT LFA MA ORG MACH GDPC $F H C$, select $\left(T=\right.$ MKM MKM2) was used. Standard errors in parentheses. $\sigma_{i}$ denotes the square root of the variance of the error terms $w_{1 i}$ and $w_{0 i}$ in the outcome equation (17) and (18), respectively; $\rho_{i}$ indicates the

Table 3.

Endogenous switching regression results correlation coefficient between the error term of the selection equation (19) and the error term of the outcome equations (17) and (18), respectively. *Significant at 10\% level; **Significant at 5\% level; ***Significant at $1 \%$ level

Unlike in the case of wine specialists, more paid labor (PL) on specialized olives farms leads to higher FNI. Non-GI farms with larger land areas (UAA), higher specific costs (SPC), lower external costs (EXT) and higher farm household consumption (FHC) achieve higher farm net incomes (FNI). Non-adopters also have higher FNI if they are located in a mountainous area (MA) and in regions with a lower GDP per capita (GDPC). For GI farms, organic production (ORG) and farm household income (FHC) lower FNI. 
Table 3 also reports estimates for $\mathrm{rho}_{1}$ ( $\rho_{i}$ for GI farms) and $\mathrm{rho}_{2}\left(\rho_{i}\right.$ for non-GI farms), the correlation coefficients between the error term of the selection equation and the error terms of the outcome equations. $\mathrm{RhO}_{2}$ is significantly negative for wine specialists and olives specialists, while rho ${ }_{1}$ is only significant, and negative, for olives specialists. According to Lokshin and Sajaia (2004), this indicates that GI olives specialists earn lower FNI than a random farm from the olives sample. An insignificant rho for GI wine specialists means that wine specialists do not earn more or less than a random farm in the sample.

Finally, Table 4 shows the estimated treatment effects for treated (ATT) and untreated farms (ATU). The estimated sample means of treated $\left(E\left(Y_{i}^{1} \mid T_{i}=1\right)\right)$ and untreated farms $\left(E\left(Y_{i}^{0} \mid T_{i}=0\right)\right)$ are close to the true sample means. For quality wine specialists, average farm net income is 20,774 EUR (ESR estimate is 20,775 EUR) for treated farms and 49,089 EUR (ESR estimate is 71,286 EUR) for untreated farms. Counterfactuals are estimated to be $-137,180$ EUR for treated farms if they had not used GI, and 45,447 EUR for untreated farms if they had used GI. This leads to an estimated treatment effect for treated farms of 157,955 EUR. This shows a very large effect of GI adoption for wine specialists. In contrast, the ATU is estimated to be $-25,839 \mathrm{EUR}$. This shows that non-adopters would earn much less if they would use GI.

For olives specialists, the true sample mean of FNI was 27,564 EUR for adopters and 23,377 EUR for non-adopters. The ESR model estimated these parameters to be 27,521 EUR and 24,033 EUR, respectively. According to the ESR results, GI olives specialists would have earned a negative profit of 35,286 EUR if they had not used GI. In contrast, untreated olives specialists would have earned 70,490 EUR if they had adopted GI, which is 46,457 EUR more than they in fact earned, according to the estimates. This finding is counterintuitive as the large income effect of adopting would incentive current non-GI farms to switch to GI production. Of course, this would assume minimal switching costs and no other barriers to adopting GI.

\section{Conclusion and discussion}

This paper performed an impact assessment of GI adoption on farm incomes for quality wine specialists and olives specialists in the EU. Our research contributes to the knowledge gap

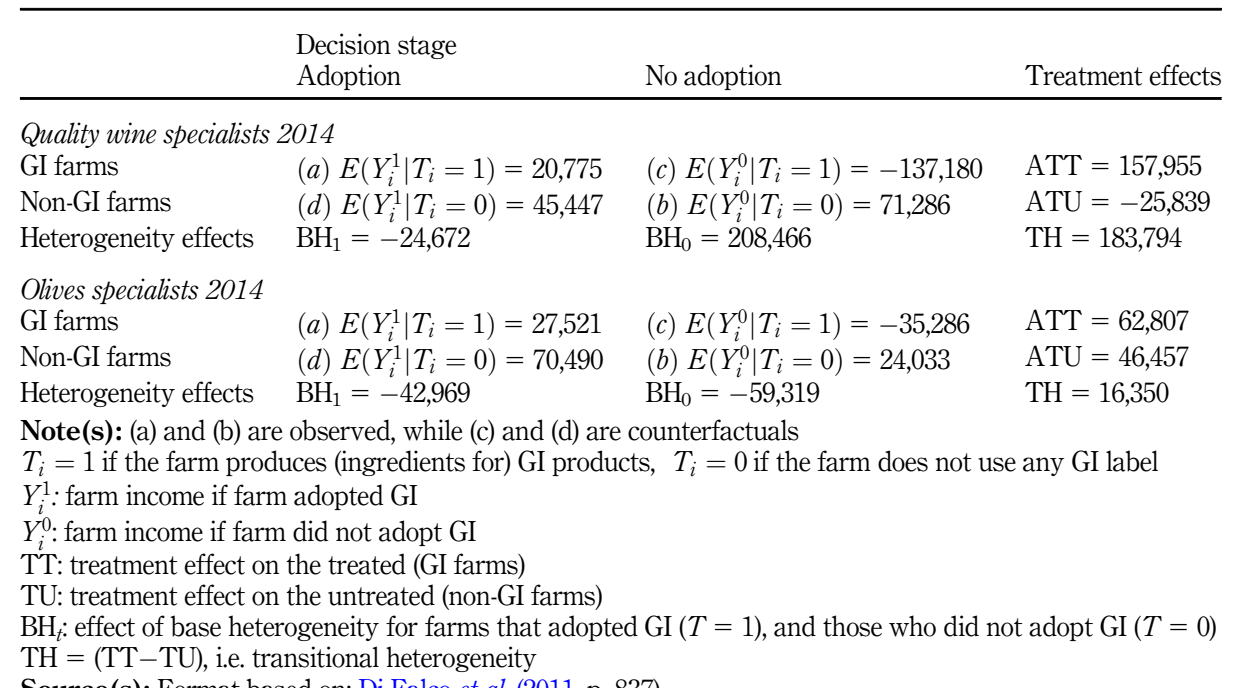

Source(s): Format based on: Di Falco et al. (2011, p. 837)
The impact of geographical indications

589 
BFJ

123,13

590

that was identified in a review by Cei et al. (2018a). They concluded that the literature on GI effects on farmers mainly uses case-study analysis, while comprehensive analyses are lacking; and that the economic indicators used are often limited to observed prices and/or costs. We extend the body of research on this topic by using a comprehensive dataset that allows for an econometric analysis and farm income as the indicator of economic performance of the farm.

Data for the analysis was derived from the Farm Accountancy Data Network and EUROSTAT for 2014. The impact of GI on farm incomes was assessed by using an endogenous switching regression model. Results were estimated by full information maximum likelihood. In a first step, the determinants of GI adoption were estimated. For wine specialists we find that farms that adopt GI are more likely to have a smaller land area on average. This is in line with findings from Bouamra-Mechemache and Chaaban (2010). Furthermore, organic production positively affects GI adoption, while regional welfare decreases the probability of GI uptake. The latter is in line with Van de Pol (2017) but contradicts the argument of Beckmann and Schimmelpfennig (2015) that higher regional welfare increases the demand for GI products. An interesting finding for olives specialists is that they are more likely to adopt GI if farms are located in less favored areas. This is in line with the objective of rural development to which the EU quality policy is expected to contribute (Council of the European Communities, 1992) and findings by Van de Pol (2017).

Next, we estimated average treatment effects of GI adoption. For wine specialists, the effect of GI on farm net income was estimated to be highly positive at 157,955 EUR. The average treatment effect for GI olives specialists was estimated to be $62,807 \mathrm{EUR}$. These estimates are in line with theoretical predictions since adopters are assumed to only adopt GI if they do not decrease their farm profits. Moreover, our findings support the positive farm income effects that are reported in the EU evaluation report of the GI policy (European Commission, 2020). It should be noted, however, that the reported effects in European Commission (2020) are based on the comparison of average incomes of adopters and nonadopters, without taking into account the potential self-selection bias that we address by using the endogenous switching model. Cei et al. (2018b) also report positive effects of GI adoption. However, the extensive review by Török et al. (2020) concludes that evidence of the impact of GI adoption on economic indicators is mixed. Our study adds to this body of literature showing yet again that the evaluation of GI is complex and outcomes are highly dependent on the methodology that is used and context-specific factors.

Comparing the results for the olives and wine sectors, we highlight that GI wine production is more connected to organic production than GI olives production. This may indicate that the olive oil sector is lagging behind the wine sector in focusing on high quality production and differentiation through both GI and organic certification. Such a conclusion is in line with findings from Cacchiarelli et al. (2016) and Carbone et al. (2018) who argue that GI and organic certification of olive oil offers little added value to consumers and this may deter olive growers from adopting GI and organic production. On the other hand, European Parliament Research Service (2017) claims that the interest in organic and GI food quality schemes is growing also for olive oils, but that consequent price premiums have made the sector vulnerable to food fraud (illegal mixing, mislabeling etc.). Frequent reports on food fraud in the olive oil sector may be detrimental for consumer trust and may deprive legitimate olive growers from reaping the benefits of price premiums for GI or organic production. Stronger monitoring and control systems, either public or private, should prevent such adverse effects from happening.

We find that GI adoption by olives specialists occurs more frequently in less favored areas; while GI wine specialists are located more often in mountainous areas. With the EU quality policy specifically targeting improved rural development in regions with natural or economic challenges (Council of the European Communities, 1992), our findings 
of positive treatment effects for wine and olives specialists suggest that this ambition may at least to some extent be achieved. It should be noted, however, that we focus exclusively on the impact on farm incomes, while positive rural development outcomes may also occur, for instance, through improved employment opportunities, limiting land abandonment and depopulation, and the preservation of local traditions and culture (European Commission, 2020). Keeping a broad perspective on rural development, that goes beyond mere income effects, is important for the design and the support for policy initiatives such as the EU food quality policy.

We also have to point out some general shortcomings with respect to the chosen model and data, which might have caused estimates to be biased. The main concern relates to the use of the FADN data for the impact assessment of GI adoption by EU farms. Several issues raise doubt about the appropriateness of FADN to allow a correct estimation of the impact of GI adoption. First, it is not possible to distinguish between farms who produce final GI products and those who only produce ingredients for GI products. Second, it is unknown whether those farms who only produce ingredients for GI products are always aware that their raw products are used downstream in GI value chains. If they are not aware that their raw products are later turned into a GI product then they would end up in the control group instead of the treated group. Third, the question about GI asked for PDO and PGI labels. It is unknown, which GI scheme was applied by adopters. The results can therefore only be interpreted as a joint effect of PDO and PGI labels.

Furthermore, it is unclear to what extent control variables of GI farms are affected by GI adoption. All impact evaluation techniques, including ESR, require control variables to be independent of treatment (Khandker et al., 2010). However, it is possible that certain types of farms have adopted GI before 2014 (the year of observation) to gain market power. This may have increased farm gate prices, output and income over time, and may have stimulated onfarm investments on these farms. As a result, differences between adopters and non-adopters in variables that we use as controls in our model, such as paid labor or land area, may have decreased over time. The estimated causal effects would then be biased. To prevent such misinterpretations, the use of baseline data is advisable (Yao et al., 2017). Baseline data reflect the conditions under which farms actually decided to use GI, so determinants of uptake can be clearly identified. Without having access to such baseline data, impact assessments must be treated with caution as it cannot be guaranteed that farm-specific characteristics are independent of treatment.

The limitations of the research therefore also point to the limitations of the FADN data to perform impact analyses of GI adoption. Adaptation of the FADN survey instrument could improve the quality of the collected data on GI involvement and hence further our understanding of GI impact on farmers.

\section{Note}

1. Nomenclature of Territorial Units for Statistics

\section{References}

Agricultural Markets Task Force (2016), "Improving market outcomes. Enhancing the position of farmers in the supply chain", Report of the Agricultural Markets Task Force, Brussels, available at: https://ec.europa.eu/agriculture/agri-markets-task-force_en.

Arfini, F. and Bellassen, V. (2019), Sustainability of European Food Quality Schemes. Multi-Performance, Structure, and Governance of PDO, PGI, and Organic Agri-Food Systems, Springer, Heidelberg.

Beckmann, J. and Schimmelpfennig, D. (2015), "Determinants of farm income", Agricultural Finance Review, Vol. 75 No. 3, pp. 385-402.
The impact of geographical indications 
BFJ 123,13
Belletti, G., Marescotti, A., Sanz-Cañada, J. and Vakoufaris, H. (2015), "Linking protection of geographical indications to the environment: evidence from the European Union olive-oil sector", Land Use Policy, Vol. 48, pp. 94-106.

Belletti, G., Marescotti, A. and Touzard, J.-M. (2017), "Geographical indications, public goods, and sustainable development: the roles of actors' strategies and public policies”, World Development, Vol. 98, pp. 45-57.

Borg, E.A. and Gratzer, K. (2013), "Collective brand strategy, entrepreneurship, and regional growth: the role of a protected designation of origin (PDO)", Journal of World Economic Research, Vol. 2 No. 3, pp. 26-38.

Bouamra-Mechemache, Z. and Chaaban, J. (2010), "Determinants of adoption of protected designation of origin label: evidence from the French Brie cheese industry", Journal of Agricultural Economics, Vol. 61 No. 2, pp. 225-239.

Bresciani, S., Ferraris, A., Santoro, G. and Nilsen, H.R. (2016a), "Wine sector: companies' performance and green economy as a means of societal marketing", Journal of Promotion Management, Vol. 22 No. 2, pp. 251-267.

Bresciani, S., Giacosa, E., Broccardo, L. and Culasso, F. (2016b), "The family variable in the French and Italian wine sector", EuroMed Journal of Business, Vol. 11 No. 1, pp. 101-118.

Cacchiarelli, L., Carbone, A., Laureti, T. and Sorrentino, A. (2016), "The value of the certifications of origin: a comparison between the Italian olive oil and wine markets", British Food Journal, Vol. 118 No. 4, pp. 824-839.

Carbone, A., Cacchiarelli, L. and Sabbatini, V. (2018), "Exploring quality and its value in the Italian olive oil market: a panel data analysis", Agricultural and Food Economics, Vol. 6 No. 6, pp. 1-15.

Cei, L., Defrancesco, E. and Stefani, G. (2018a), "From geographical indications to rural development: a review of the economic effects of European Union policy", Sustainability, Vol. 10 No. 3745, pp. 1-21, doi: 10.3390/su10103745.

Cei, L., Stefani, G., Defrancesco, E. and Lombardi, G.V. (2018b), "Geographical indications: a first assessment of the impact on rural development in Italian NUTS3 regions", Land Use Policy, Vol. 75, pp. 620-630.

Council of the European Communities (1992), "Council regulation (EEC) No 2081/92 on the protection of geographical indications and designations of origin for agricultural products and foodstuffs", available at: https://eur-lex.europa.eu/eli/reg/1992/2081/oj.

Deselnicu, O.A., Costanigro, M., Souza-Monteiro, D.M. and Thilmany-McFadden, D. (2013), "A metaanalysis of geographical indication food valuation studies: what drives the premium for originbased labels?”, Journal of Agricultural and Resource Economics, Vol. 38 No. 2, pp. 204-219.

Di Falco, S., Veronesi, M. and Yesuf, M. (2011), "Does adaptation to climate change provide food security? A micro-perspective from Ethiopia", American Journal of Agricultural Economics, Vol. 93 No. 3, pp. 829-846.

Dixit, S.K. (2020), "Marketing gastronomic tourism experiences", in Dixit, S.K. (Ed.), The Routledge Handbook of Tourism Experience Management and Marketing, Routledge, Taylor \& Francis Group, London, Chapter 28.

Donati, M., Wilkinson, A., Veneziani, M., Antonioli, F., Arfini, F., Bodini, A., Amilien, V., Csillag, P., Ferrer-Pérez, H., Gkatsikos, A., Gauvrit, L., Gil, C., Hoàng, V., Knutsen Steinnes, K., Lilavanichakul, A., Mattas, K., Napasintuwong, O., Nguyen, A., Nguyen, M., Papadopoulos, I., Ristic, B., Stojanovic, Z., Tomić Maksan, M., Török, Á., Tsakiridou, E. and Bellassen, V. (2020), "Economic spill-over of food quality schemes on their territory", Journal of Agricultural and Food Industrial Organization, doi: 10.1515/jafio-2019-0046.

European Commission (2009), "Why do we need a common agricultural policy?", Discussion paper by DG Agriculture and Rural Development.

European Commission (2011), EU Agricultural Economic Briefs. What Is a Small Farm? Brief No 2, Agriculture and Rural Development, European Commission, Brussels. 
European Commission (2016), "Farm accountancy data network", available at: ec.europa.eu/ agriculture/rica/methodology2_en.cfm (accessed 14 August 2018).

European Commission (2017), "CAP post-2013: key graphs and figures. Share of direct payments and total subsidies in agricultural factor income", available at: https:/ec.europa.eu/agriculture/sites/ agriculture/files/cap-post-2013/graphs/graph5_en.pdf (accessed 7 May 2018).

European Commission (2020), "Evaluation support study on geographical indications and traditional specialities guaranteed protected in the EU", available at: https://op.europa.eu/en/publicationdetail/-/publication/c1d86ba1-7b09-11eb-9ac9-01aa75ed71a1/language-en.

European Parliament Research Service (2017), The EU Olive and Olive Oil Sector. Main Features, Challenges and Prospects, Briefing for the European Parliament, European Parliament Research Service, Brussels, available at: https:/www.europarl.europa.eu/thinktank/en/ document.html?reference=EPRS_BRI(2017)608690.

Gangjee, D.S. (2017), "Proving provenance? Geographical indications certification and its ambiguities", World Development, Vol. 98, pp. 12-24.

Giovannucci, D., Josling, T., Kerr, W., O'Conner, B. and Yeung, M.T. (2009), Guide to Geographical Indications: Linking Products and Their Origins, International Trade Centre, Geneva.

Hajdukiewicz, A. (2014), "European Union agri-food quality schemes for the protection and promotion of geographical indications and traditional specialities: an economic perspective", Folia Horticulturae, Vol. 26 No. 1, pp. 3-17.

Hazell, P.B.R. (2005), "Is there a future for small farms?”, Agricultural Economics, Vol. 32 No. s1, pp. 93-101.

Hill, B. and Brandley, B.D. (2015), Comparison of Farmers' Incomes in the EU Member States, Report for European Parliament, DG Internal Policies, European Commission, Brussels.

Jantyik, L. and Török, A. (2020), "Estimating the market share and price premium of GI foods-the case of the Hungarian food discounters", Sustainability, Vol. 12 No. 1094, pp. 1-15.

Khandker, S.R., Koolwal, G.B. and Samad, H.A. (2010), Handbook on Impact Evaluation. Quantitative Methods and Practices, The World Bank, Washington.

Khonje, M., Manda, J., Alene, A.D. and Kassie, M. (2015), "Analysis of adoption and impacts of improved maize varieties in Eastern Zambia”, World Development, Vol. 66, pp. 695-706.

Langreo, N.A. (2010), "Business strategies in the olive oil sector and their impact on the value chain", Paper Presented to the IOC Advisory Committee Essaouira, 22 June 2010.

Li, J., Ma, W., Renwick, A. and Zheng, H. (2020), "The impact of access to irrigation on rural incomes and diversification: evidence from China", China Agricultural Economic Review, Vol. 12 No. 4, pp. 705-725.

Lokshin, M. and Sajaia, Z. (2004), "Maximum likelihood estimation of endogenous switching regression models", The Stata Journal, Vol. 4 No. 3, pp. 282-289.

Lopez-Bayon, S., Gonzalez-Díaz, M., Solís-Rodríguez, V. and Fernandez-Barcala, M. (2018), "Governance decisions in the supply chain and quality performance: the synergistic effect of geographical indications and ownership structure", International Journal of Production Economics, Vol. 197, pp. 1-12.

Lopez-Bayon, S., Fernández-Barcala, M. and González-Díaz, M. (2020), "In search of agri-food quality for wine: is it enough to join a geographical indication?", Agribusiness, Vol. 36, pp. 568-590.

Mattas, K., Baourakis, G., Tsakiridou, E., Hedoui, M.A. and Hosni, H. (2020), "PDO olive oil products: a powerful tool for farmers and rural areas", Journal of International Food and Agribusiness Marketing, Vol. 32 No. 4, pp. 313-336.

Meraner, M., Heijman, W., Kuhlman, T. and Finger, R. (2015), "Determinants of farm diversification in The Netherlands", Land Use Policy, Vol. 42, pp. 767-780.

Merli, R., Preziosi, M. and Acampora, A. (2018), "Sustainability experiences in the wine sector: toward the development of an international indicators system", Journal of Cleaner Production, Vol. 172, pp. 3791-3805.
The impact of geographical indications 
BFJ 123,13

594

Monier-Dilhan, S., Poméon, T., Böhm, M., Brečić, R., Csillag, P., Donati, M., Ferrer-Pérez, H., Gauvrit, L., Gil, J.M., Hoàng, V., Lilavanichakul, A., Majewski, E., Malak-Rawlikowska, A., Mattas, K., Napasintuwong, O., Nguyễn, A.Q., Nikolaou, K., Papadopoulos, I., Pascucci, P., Peerlings, J., Ristic, B., Steinnes, K., Stojanovic, Z., Tomić Maksan, M., Török, A., Veneziani, M., Vittersø, G. and Bellassen, V. (2020), "Do food quality schemes and net price premiums go together?", Journal of Agricultural and Food Industrial Organization, Vol. 19 No. 2, pp. 1-16, doi: 10.1515/ jafio-2019-0044.

Prakash, A. (Ed.), Organisation des Nations Unies pour l'alimentation et l'agriculture (2011), Safeguarding Food Security in Volatile Global Markets, Food and Agricultural Organisation, Rome.

Recanati, F., Maughan, C., Pedrotti, M., Dembska, K. and Antonelli, M. (2019), "Assessing the role of CAP for more sustainable and healthier food systems in Europe: a literature review", Science of The Total Environment, Vol. 653 No. 25, pp. 908-919.

Rugani, B., Vázquez-Rowe, I., Benedetto, G. and Benetto, E. (2013), “A comprehensive review of carbon footprint analysis as an extended environmental indicator in the wine sector", Journal of Cleaner Production, Vol. 54, pp. 61-77.

Szolnoki, G. (2013), "A cross-national comparison of sustainability in the wine industry", Journal of Cleaner Production, Vol. 53, pp. 243-251.

Török, A., Jantyik, L., Maró, Z.M. and Moir, H.V.J. (2020), "Understanding the real-world impact of geographical indications: a critical review of the empirical economic literature", Sustainability, Vol. 12 No. 9434, pp. 1-24.

Vázquez-Rowe, I., Rugani, B. and Benetto, E. (2013), “Tapping carbon footprint variations in the European wine sector", Journal of Cleaner Production, Vol. 43, pp. 146-155.

Van de Pol, L. (2017), Explaining the Spatial Distribution in the Uptake of PDO and PGI in Europe, MSc thesis report Wageningen University \& Research, Wageningen.

Van Haeck, C., Meloni, G. and Swinnen, J. (2019), "The value of terroir: a historical analysis of the Bordeaux and champagne geographical indications", Applied Economic Perspectives and Policy, Vol. 41 No. 4, pp. 598-619.

Van Ittersum, K. (2002), The Role of Region of Origin in Consumer Decision-Making and Choice, Mansholt Graduate School, Wageningen.

Verbeke, W., Pieniak, Z., Guerrero, L. and Hersleth, M. (2012), "Consumers' awareness and attitudinal determinants of European Union quality label use on traditional foods", Bio-based and Applied Economics, Vol. 1 No. 2, pp. 213-229.

Weissteiner, C.J., Boschetti, M., Böttcher, K., Carrara, P., Bordogna, G. and Brivio, P.A. (2011), "Spatial explicit assessment of rural land abandonment in the Mediterranean area", Global and Planetary Change, Vol. 79, pp. 20-36.

Yao, X.I., Wang, X., Speicher, P.J., Hwang, E.S., Cheng, P., Harpole, D.H., Berry, M.F., Schrag, D. and Pang, H.H. (2017), "Reporting and guidelines in propensity score analysis: a systematic review of cancer and cancer surgical studies", Journal of the National Cancer Institute, Vol. 109 No. 8, p. 323.

\section{Corresponding author}

Liesbeth Dries can be contacted at: liesbeth.dries@wur.nl 


\section{Appendix A1}

\begin{tabular}{|c|c|c|c|c|c|}
\hline $\begin{array}{l}\text { Variable } \\
\text { code }\end{array}$ & Original code & Source & Description & Scale & Level \\
\hline $\mathrm{T}$ & A_CL_150_C & FADN & $\begin{array}{l}\text { 2014: Indication for whether the holding } \\
\text { produces agricultural products and/or } \\
\text { foodstuffs protected by a PDO or PGI or } \\
\text { whether it produces agricultural products } \\
\text { which are known to be used to produce } \\
\text { foodstuffs protected by PDO/PGI within the } \\
\text { meaning of Council regulation (EC) No 510/ } \\
2006 \\
2015 \text { : Indication for whether the holding } \\
\text { produces agricultural products and/or } \\
\text { foodstuffs protected by a PDO/PGI/TSG/ } \\
\text { mountain product or whether it produces } \\
\text { agricultural products which are known to be } \\
\text { used to produce foodstuffs protected by PDO/ } \\
\text { PGI/TSG/mountain product within the } \\
\text { meaning of Council regulation } \\
\text { (EC) No } 1151 / 2012 \\
\text { Code numbers: } 1 \text { ) no } 2 \text { ) only } 3 \text { ) some } \\
\text { First, all farms with A_CL_150_C = } 3 \text { were } \\
\text { excluded from the sample (those with missing } \\
\text { data as well) } \\
\text { Next, a dummy variable was generated with } \\
T=1 \text { if A_CL_150_C = } 2 \text { and } T=0 \text { if } \\
\text { A_CL_150_C = } 1\end{array}$ & $\begin{array}{l}\text { Dichotomous } \\
\text { (yes/no) }\end{array}$ & Farm \\
\hline FNI & SE420 & FADN & $\begin{array}{l}\text { Farm net income in EUR; remuneration to fixed } \\
\text { factors of production (work, land, capital) and } \\
\text { remuneration to the entrepreneurs' risk (loss/ } \\
\text { profit) in the accounting year; = Total output } \\
\text { (SE131) - Total intermediate consumption } \\
\text { (= Total specific costs + Total farming } \\
\text { overheads; SE275) + Balance current subsidies } \\
\text { and taxes (SE600) - Depreciation } \\
\text { (SE360) + Balance subsidies and taxes on } \\
\text { investments (SE405) - Total external factors } \\
\text { (= Wages paid + Interest paid + Rent paid, } \\
\text { SE365); } \\
\text { If unpaid (family) labour >0, FNI = family farm } \\
\text { income (FFI) }\end{array}$ & Continuous & Farm \\
\hline OUT & SE131 & FADN & Total output in EUR & Continuous & Farm \\
\hline $\mathrm{SPC}$ & SE281 & FADN & Total specific costs in EUR & Continuous & Farm \\
\hline OVER & SE336 & FADN & $\begin{array}{l}\text { Total farming overheads in EUR; supply costs } \\
\text { linked to production activity but not linked to } \\
\text { specific lines of production }\end{array}$ & Continuous & Farm \\
\hline PL & SE020 & FADN & $\begin{array}{l}\text { Paid labor input in annual working units } \\
\text { (AWU) }\end{array}$ & Continuous & Farm \\
\hline UL & SE015 & FADN & Unpaid labor input in AWU & Continuous & Farm \\
\hline LIA & SE485 & FADN & & & \\
\hline UAA & SE025 & FADN & $\begin{array}{l}\text { Total utilized agricultural area in ha; does not } \\
\text { include areas used for mushrooms, land rented } \\
\text { or less than one year on an occasional basis, } \\
\text { woodland and other farm areas (roads, ponds, } \\
\text { non-farmed areas, etc.); it consists of land in } \\
\text { owner occupation, rented land and land in } \\
\text { share-cropping; it includes agricultural land } \\
\text { temporarily not under cultivation for } \\
\text { agricultural reasons or being withdrawn from } \\
\text { production as part of agricultural policy } \\
\text { measures }\end{array}$ & Continuous & Farm \\
\hline
\end{tabular}

(continued)
The impact of geographical indications 
BFJ
123,13

\begin{tabular}{llllll}
$\begin{array}{l}\text { Variable } \\
\text { code }\end{array}$ & Original code & Source & Description & Scale & Level \\
\hline EXT & SE365 & FADN & $\begin{array}{l}\text { Total external factors in EUR; remuneration of } \\
\text { inputs (labor, land, capital) which are not the } \\
\text { property of the holder; includes wages, rent and }\end{array}$ & Continuous & Farm \\
interest paid & $\begin{array}{l}\text { Less favored area; A_CL_160_C has the } \\
\text { following code numbers: } \\
\text { LFA }\end{array}$ & $\begin{array}{l}\text { Based on } \\
\text { A_CL_160_C }\end{array}$ & FADN & $\begin{array}{l}\text { Dichotomous } \\
\text { (yes/no) }\end{array}$ & Farm \\
& & & &
\end{tabular}

In 2014: (1) majority of the UAA of the holding is not situated in a less favored area, (2) majority of the UAA of the holding is situated in a LFA, (3) majority of the UAA of the holding is situated in a mountainous area, (4) the areas are so small and numerous in these member states that the information is not significant A dummy variable was generated with $\mathrm{LFA}=1$ if A_CL_160_C $=2$ and LFA $=0$ for the rest

$\begin{array}{lll}\text { MA } & \begin{array}{l}\text { Based on } \\ \text { A_CL_160_C }\end{array} & \text { FADN } \\ & & \\ \text { ORG } & \begin{array}{l}\text { Based on } \\ \text { A_CL_140_C }\end{array} & \text { FADN } \\ & & \end{array}$

Mountainous area; See LFA; A dummy variable was generated with $\mathrm{MA}=1$ if A_CL_160_C $=3$ and MA $=0$ for the rest Organic production; A_CL_140_C has the following code numbers: (1) holding does not apply organic production methods, (2) holding applies only organic production methods, (3) holding applies both organic and other production methods, (4) holding is converting to organic production methods

A dummy variable was generated with $\mathrm{ORG}=1$ if A_CL_140_C $=2$ (only organic)

$\begin{array}{llll}\text { MACH } & \text { SE455 } & \text { FADN } & \text { Value of machinery in EUR } \\ \text { FHC } & \text { SE260 } & \text { FADN } & \text { Farm household consumption in EUR } \\ \text { GDPC } & \text { GDP_inh } & \text { Van de } & \begin{array}{l}\text { GDP per inhabitant in EUR in a specific NUTS2 } \\ \text { region in } 2013\end{array} \\ \text { MKM } & \text { Mol(2017) } & \text { Van de } & \text { Km of motorway per } 1000 \mathrm{~km}^{2} \text { in a specific } \\ & & \begin{array}{l}\text { Pol }(2017) \\ \text { NUTS2 region in } 2013\end{array} \\ \text { MKM2 } & \text { Based on } & \text { Van de } & \text { Square of MKM } \\ & \text { MW_km2 } & \text { Pol(2017) } & \end{array}$

Continuous Farm

Continuous Farm

Continuous NUTS2

Continuous NUTS2

Continuous NUTS2

Table A1.

Pol (2017) 


\section{Appendix A2}

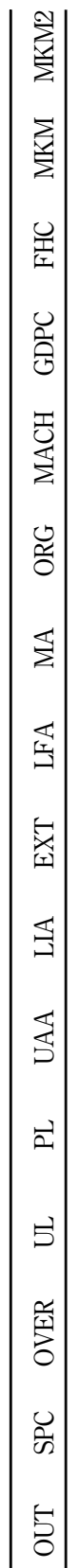

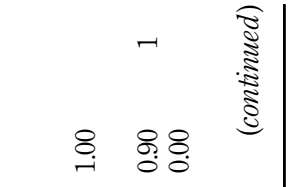

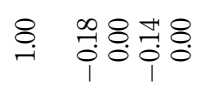

\&

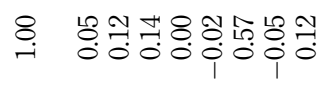

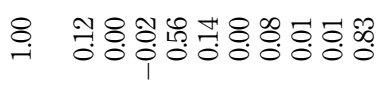

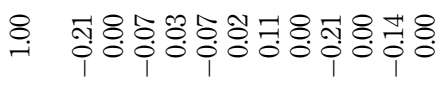

\&

\&

\&

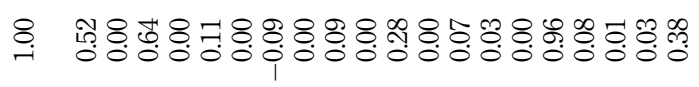

\&

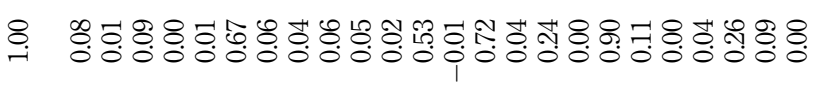

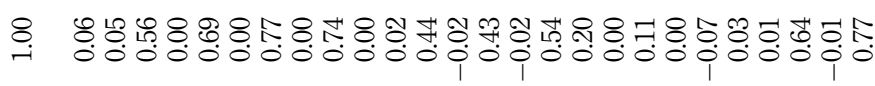

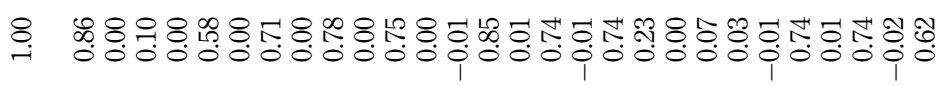

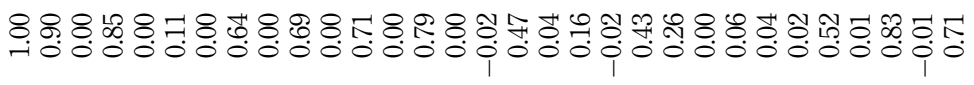

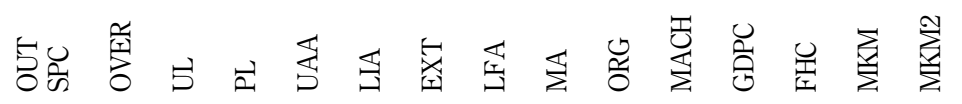

The impact of geographical indications

597
Table A2. Correlation coefficients explanatory variables - olives specialists 


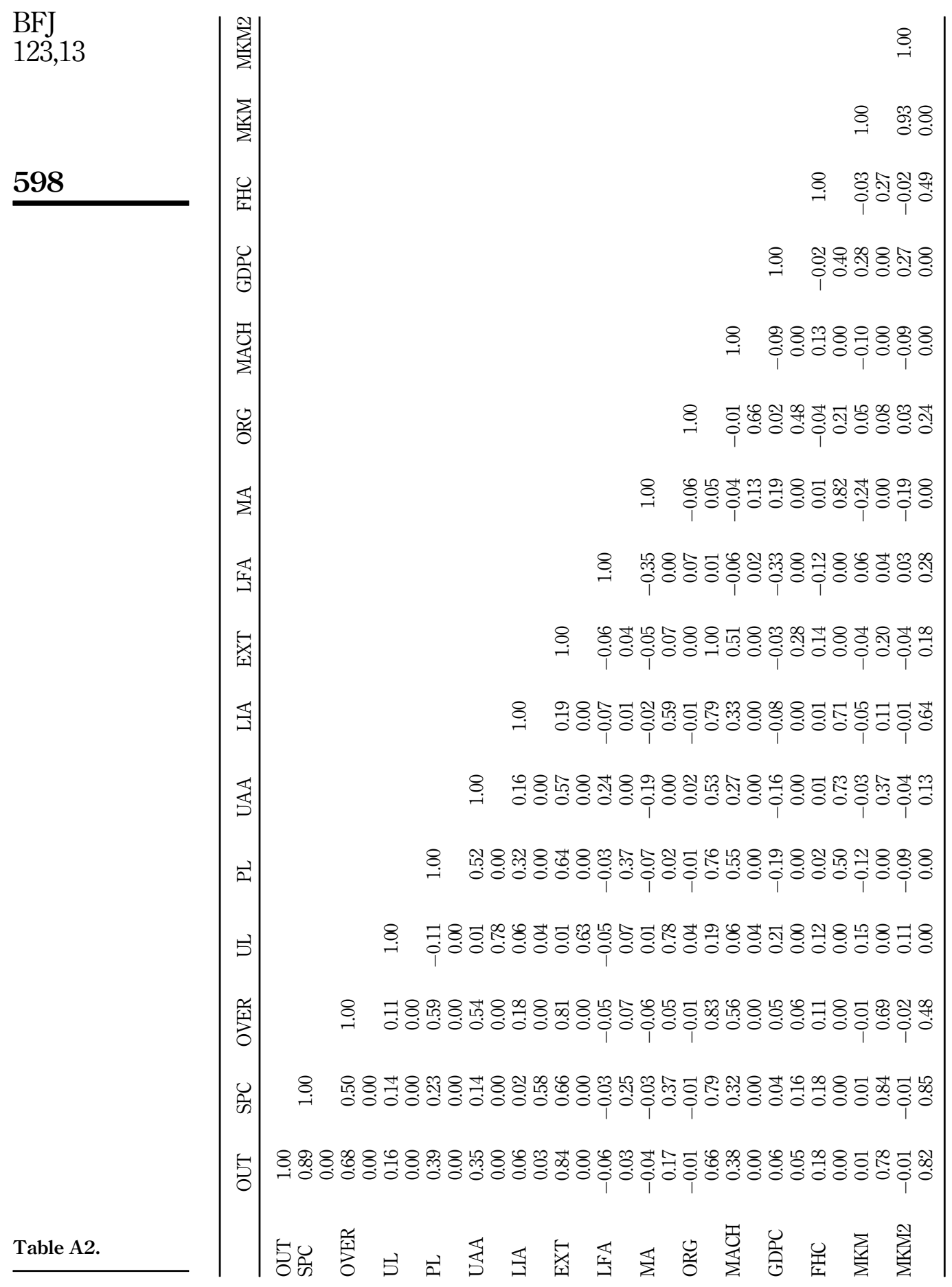

